\title{
COVID-19 AND EUROPEAN UNION - THE ANSWER TO THE HEALTH CRISIS AS A WAY FOR RESUMING THE PROCESS OF EUROPEAN INTEGRATION
}

\author{
Stelio Mangiameli ${ }^{1}$
}

\section{Abstract}

The essay starts from a comparison in the European Union between the economic and financial crisis of 2009 and the health crisis of 2020, due to the Covid-19 pandemic. In particular, the scarce capacity of Member States and European institutions to carry out the recovery of the economic European condition and transformation of the European government system after the 2009 crisis, despite the indications of the Commission's Blueprint (of 2012) and of the Report of the five presidents (of 2015). On the other hand, in the face of the health crisis, the reaction of the European institutions seemed more decisive with the creation of various instruments to combat the economic consequences of the Covid-19 pandemic. These include in particular the Recovery fund - Next Generation EU, linked to the 2021-2027 MFF. The reaction to the pandemic shows the possibilities of the European Union to create a community of States in solidarity and with its own identity also in the international scenario. However, it is by no means certain that this idea can prevail over the one that sees the European Union as simply a free trade organization between the Member States. The decisions that will be taken in the Conference on the future of Europe between 2021 and 2022 appear to be decided to define the evolution of the European Union.

\section{Keywords}

The European Treaties. The Maastricht Treaty. The Constitutional Treaty. The Lisbon Treaty. European Union and economic and financial crisis. European Union and Covid19 pandemic.

\section{Summary}

1. The European Union before the economic and financial crisis. - 2. The Lisbon Treaty and the economic and financial crisis. - 3. The European Union after the economic and financial crisis. - 4. The 2019 parliamentary elections, the von der Leyen Commission and the review of the ESM Treaty. - 5. The EU response to the Covid-19 pandemic and the new 2021-2027 MFF. - 6. The evaluation of the instruments to combat the Covid-19 pandemic. - 7. The reaction to the Covid-19 pandemic and the future of the European Union.

${ }^{1}$ Full Professor. Teramo University (Italy) 
"It is expedient that on the second Monday in May next a Convention of delegates who shall have been appointed by the several states be held at Philadelphia for the sole and express purpose of revising the Articles of Confederation and reporting to Congress and the several legislatures such alterations and provisions therein as shall when agreed to in Congress and confirmed by the states render the federal constitution adequate to the exigencies of Government \& the preservation of the Union".

Report of Proceedings in Congress; February 21, 1787

Journals of the Continental Congress, vol. 38 (manuscript), Library of Congress

\section{THE EUROPEAN UNION BEFORE THE ECONOMIC AND FINANCIAL CRISIS}

Crises are at the root of change. They move forces that involve the questioning of the status quo, as this is the cause of the crisis, or appears unable to resolve the crisis, and determine the need to build new political, economic and social assets. ${ }^{2}$

Of course, it is not certain that the new arrangements will be better than the previous ones or fairer or more advantageous than those that preceded them, because this will depend on the decisions that will be taken.

Social communities guided in an intelligent, responsible and resilient way in the face of a crisis will be able to face it by managing to achieve an ameliorative transformation; on the contrary, where the leadership of the

2 On the concept or notion of crisis in the social sciences, see R. KOSELLECK, 1972-97, Bd. 3, 617-650. 


\section{Mangiameli ICOVID-19 AND EUROPEAN UNIONI ISSN 2675-1038}

society has been entrusted to mediocre people or people with limited views or poor intellect, the crisis can almost certainly end in tragedy.

This way of looking at the crisis and change is valid for every kind of community and for the government that it has given itself and therefore it can concern States, Regions and Cities, as well as international and supranational institutions such as the European Union ${ }^{3}$.

With reference to the latter, we can consider two examples of consequences of a crisis: on the one hand, the economic and financial crisis of 2008 that affected the European Union in the last twelve years ${ }^{4}$ and, on the other, the health crisis that hit the world and Europe due to the Covid-19 pandemic, starting from January 2020.

It can immediately be said that the response to the economic crisis and that to the pandemic crisis by the European Institutions do not seem to resemble each other and their management by the European Union also appears different. It is not certain that this is due to the teaching that the European Institutions and the Member States have drawn from the first crisis, even if it was immediately evident that the economic and financial crisis had an asymmetrical character and the pandemic crisis, on the other hand, was presented with a symmetrical character.

However, in order to understand the differences and make a comparison of the management of the two crises, it appears necessary to put forward some considerations on the institutional condition of the European Union in

3 The whole history of European integration is marked by crises that have always called into question the possibility of survival of the European Institutions; but, history shows the political capacity before the European Community and after the European Union to overcome the fractures caused by historical events; see, on this subject, the pages written by H. SCHMIDT, 2002, 130-137, which recalled the words of Jean Monnet: "Step by step" (Schritt für Schritt)

${ }^{4}$ See S. MANGIAMELI (Ed.), 2017. 


\section{Mangiameli ICOVID-19 AND EUROPEAN UNIONI ISSN 2675-1038}

2009, before the economic and financial crisis, born in the United States, was imported into Europe 5 .

In this regard, it must be remembered that the signature and entry into force of the Maastricht Treaty (1992/93) laid the foundations for an unprecedented integration process with the establishment of European citizenship $^{6}$ and the provision of the protection of fundamental rights, as general principles of the European order (art. 6, para. 2, TEU) ${ }^{7}$, the launch of the monetary union which in 1999 led to the single currency, the euro, the resumption of a common foreign and security policy, including defense, and the judicial and police cooperation and, last not least, a common visa, asylum and immigration policy ${ }^{8}$.

To this were added the more than twenty European policies that had matured in the time span from the establishment of the European Communities (1950/1957), up to the Single European Act (1986), which the Maastricht Treaty took up and reorganized in a framework in which the

5 To understand the construction of Europe, one must consider the effects produced by the leadership of Jacques Delors at the head of the Commission for three terms (see G. ROSS, 1995).

${ }^{6}$ F. CUOCOLO, 1991, 659 ss. U. EVERLING, 1992, 241 ss.; M. PIERANGELINI, 1993, 181 ss.; V. LIPPOLIS, 1994; A. RANDELZHOFER, 1995, 581 ss.; S. CASSESE, 1996, 869 ss.; M. CARTABIA, 1996; S. BARTOLE, 2000, 39 ss.

${ }^{7}$ See the Art. 6, para. 2, TEU "The Union shall respect fundamental rights, as guaranteed by the European Convention for the Protection of Human Rights and Fundamental Freedoms signed in Rome on 4 November 1950 and as they result from the constitutional traditions common to the Member States, as general principles of Community law" (C. STUMPF, 2000, 81 ss.; T. KINGREEN, 2002, 61 ss.; see also M. PAGANO, 1996, 173 ss.; G. NEGRI, 1997, 782 ss.; M. MICHETTI, 2006, 147-194).

${ }^{8}$ See J. CLOOS - G. REINESCH - D. VIGNES - J. WEYLAND, 1993; R. DEHOUSSE (Ed.), 1994; A. DUFF, J. PINDER \& R. PRYCE, 1994; F. ESTERBAUER, 1994; K. DYSON - K. FEATHERSTONE, 1999. 


\section{Mangiameli ICOVID-19 AND EUROPEAN UNIONI ISSN 2675-1038}

European Union pursues its objectives in compliance with the principle of subsidiarity (art. 2 TEU and art. 5 TEC) ${ }^{9}$.

The Maastricht Treaty, despite its signing, was not fully welcomed by the governments of the Member States, as it appeared to have made too many steps in the unification process and removed many powers at the national level. Thus negotiations began which, with the Treaty of Amsterdam (1997), led to accentuating the weight of European subsidiarity, as well as that of the participation of national parliaments and to introduce some changes aimed at carefully surrounding European citizenship. ${ }^{10}$

Monetary Union acted as a counterweight, which in the meantime was reaching its realization and whose advantages favoured a process of deepening the European Union and the process of its enlargement. The first began with the white paper on European Governance (2001) ${ }^{11}$ and with the convocation of the Laeken Convention ${ }^{12}$ which led to the formulation of

9 See C. CALLIES, 1999, 307; E. GRABITZ, 1992, 139; P.M. SCHMIDHUBER, 1993, 417 ss.; W. Kahl, 1993, 414 ss.; W. MÖSCHEL, 1993, 3025 ss.; K.W. NÖRR, T. OPPERMANN (Hrsg.), 1997; H. TIMMERMANN (Hrsg.), 1998; P. CARETTI, 1993, 7 ss.; G. D’AGNOLO, 2005, 59 ss.

${ }^{10}$ On the Treaty of Amsterdam see: R. BARENTS, 1997, 332; C. BLUMANN, 1997, 741; R. DEHOUSSE, 1997, 265; J.M. FAVRET, 1997, 555; S. NEGRI, 1997, 782 ss.; N. M. BLOKKER, T. HEUKELS, M.T.A. BRUS (Eds), 1998; S. LANGRISH, 1998, 3 ss.; Ph. MANIN, 1998, 1 ss.; M. PETITE, 1998; L.S. ROSSI, 1998, 341 ss.; J. SHAW, 1998a; J. SHAW, 1998b, 63; R. STREINZ, 1998, 137; A. TIZZANO, 1998; J.H.H. WEILER, 1998, 223; I. PERNICE, 1999, 703-750.

${ }^{11}$ See European Commission, European Governance: A white paper, COM(2001) 428/final, 5.8.2001 (see A. Sloat, 2003, 128-136).

12 The European Convention for the drafting of the Constitution was inspired by the Laeken declaration on the future of Europe (European Council meeting in Laeken 14 and 15 December 2001, Presidency Conclusions), see A. PACE, 2002, 622-623; L. HOFFMANN, 2002. The reports of the Convention can be read on the website "The European Parliament and the draft European Constitution" (http://www.europarl.eu.int/europe2004/index_it.htm). 


\section{Mangiameli ICOVID-19 AND EUROPEAN UNIONI ISSN 2675-1038}

the Constitutional Treaty $(2004)^{13}$; the second came true through the passage of the Union first to 25 Member States, with the entry, in 2004, of Poland, the Czech Republic, Slovakia, Hungary, Estonia, Latvia, Lithuania, Slovenia, Cyprus and Malta, and later to 27, with the accession of Bulgaria and Romania in $2007^{14}$.

In practice, between the deepening of the European Union and its enlargement, the latter prevailed. As is well known, the Constitutional Treaty fell under the veto of Dutch and French referendums (2005). In this way, a constitutional crisis in Europe opened, which after two years (considered as a "reflection period"- in the words of Jean Claude Juncker) led to the abandonment of the Constitutional Treaty ${ }^{15}$.

With the resumption of negotiations, part of the work of the Laeken Convention was recovered and the Treaty amending the European Treaties (2007) was approved in Lisbon. It entered into force, following the

13 On the Constitutional Treaty see H.-J. BLANKE, 2003, 95-148; U. DRAETTA, 2004, 525; R. STREINZ, 2005, 5; H.-J. BLANKE, S. MANGIAMELI, 2006; N. JÄÄSKINEN, 2011, 12: 205-218.

${ }^{14}$ See G. BUSIA, 2003 59-70; G. GUZZETTA, F. BINDI (a cura di), 2009.

${ }^{15}$ As is well known, the Convention completed its work in 2003 by delivering the text of the Treaty to the Thessaloniki Conference which subsequently, with some adjustments, formed the basis of the Treaty signed in Rome on 24 October 2004, but the events linked to the ratification produced, first, the arrest of the procedure for entry into force (2005) and, then, the abandonment of the Treaty itself (2007); see J.C. Juncker, Press Release of 17 June 2005 ("this leads us to think that a period for reflection, clarification and discussion is called for both in the countries which have ratified the Treaty and in those which have still to do so"); on the reflection period see G. Austin, 2005; I. FRIEDERICH, 2005, vol. 2, 53; A. SKORDAS, Winter 2005/2006, 241; J. PRIBAN, 2005, 135; F. SNYDER, 2005, 259; G. DE BURCA, 2006, 6; N. WALKER, 2006, 12; J. SCHWARZ, 2006, 199; L. DANIELE, 2006, 1 ss.; V. STARACE, 2006, 9 ss. 
constitutional procedures of ratification and execution by the Member States, the $1^{\text {st }}$ December 2009. ${ }^{16}$

\section{THE LISBON TREATY AND THE ECONOMIC AND FINANCIAL CRISIS}

The Treaty of Lisbon strips the European integration process of its politicalconstitutional connotations $^{17}$ and, while maintaining the complex of European policies, limits the regulatory powers of these in detail, with the aim of limiting European action as much as possible and to restore powers to the national level ${ }^{18}$. In this way, the creation of a European economic policy is made more difficult, especially since even after the Lisbon Treaty there remain considerable limits in the European system, such as the "stability and growth pact" (SGP) which aims more at stability, forgetting about growth; the lack of European budgetary policy; a system of own

16 With reference to the Lisbon Treaty, it is permitted to refer to H.-J. BLANKE - S. MANGIAMELI (Eds.), 2012; see also I. PERNICE (Hrsg.), 2008; J. SCHWARZE - A. HATJE (Hrsg.), 2009; P. CRAIG, 2010; J.-C. PIRIS, 2010; A. BIONDI, P. EECKHOUT, S. RIPLEY (Eds), 2012.

${ }^{17}$ See Council of the European Union, 26 June 2007, n. 11218/07, POLGEN 74, Note from General Secretariat of the Council, to Delegations - Subject: IGC 2007 Mandate (for an examination of these events, see S. Mangiameli, 2008, 385 ss.).

${ }^{18}$ In other words, the way in which the division of competences between the European Union and the Member States was defined by the Lisbon Treaty has determined the ineffectiveness of the European response to the economic crisis. See R. BARATTA, 2009, 109 ff.; A. BENZ, C. ZIMMER, 2012, 1-31; B. BRAAMS, 2008, 115-134; F. CARUSO, 2008, 943 ff.; H.P. FOLZ, 2009, 65-75; S. GARBEN, I. GOVAERE (Eds), 2017; F. JURGENS, 2010; T. KOSTANDINIDES, 2009; S. MANGIAMELI, 2017, 139-163; C.F. MOLINA del POZO, 2010, 85 ff.; L.S. ROSSI, 2012, 85 ff.; D. SCHARF, 2009. G.L. TOSATO, 2012, 67-78; A. WEBER, 2012, 311-322; D. WYATT, 2011, 3 ff.; J. ZILLER, 2010, $751 \mathrm{ff}$. 
resources inadequate and clearly insufficient to promote a leadership role of the European Union. ${ }^{19}$

It is also clear that the Lisbon Treaty was written when the European economy was still growing and the economic and financial crisis was not foreseeable. As a result, the European Union found itself wholly unprepared for the shock of the crisis; it lacked the necessary economic policy tools to react to the negative economic situation and this could also put the euro into question. What was worse, was that even the Member States could not carry out an anti-cyclical policy by using the budget deficit. In fact, the Stability and Growth Pact squeezed the budgets of Member States within the cage of European constraints, with the measurement of their deficit and debt, and this did not allow them to act to recover sufficient financial resources to make investments and recover a new expansive economic cycle. $^{20}$

This impasse, aggravated by the asymmetrical nature of the economic and financial crisis, exploded dramatically with the worsening of the situation in Greece (from the end of 2009 until 2012), whose government had to accept European aid, sacrificing even more its own economy ${ }^{21}$.

${ }_{19}$ On the SGP and its changes over time, see: R. BEETSMA, A. ULIGH, 1999, 546-571; A. BRUNILA, M. BUTI, D. FRANCO, 2001; P. DE GRAUWE, 2003; MULTIPLE AUTHORS, 2003, 4-18; B. HERZOG, 2004; MULTIPLE AUTHORS, 2005, 4-21; J. FISCHER, L. JONUNG, M. LARCH, 2006; K. HENTSCHELMANN, 2010; M. HEIPERTZ, A. VERDUN, 2010; L. SCHUKNECHT, Ph. MOUTOT, Ph. ROTHER, J. STARK, 2011; M. LARCH, L. JONUNG, 2014; N. R. BAERG, M. HALLERBERG, 2016, 968-1009; J. MIRANDA SARMENTO, 2018, 1-35.

${ }^{20}$ On this topic see considerations S. MANGIAMELI, 2017, 189-216.

${ }^{21}$ See the page of the European Commission where the documents of financial assistance to Greece are collected: http://ec.europa.eu/economy finance/assistance eu ms/greek loan facility/index en. htm. See also A. VITERBO, R. CISOTTA, 2010, 961 ss.; G. KARYOTIS, R. GERODIMOS (Eds.), 2015. 


\section{Mangiameli ICOVID-19 AND EUROPEAN UNIONI ISSN 2675-1038}

From the institutional point of view, the European Treaties, which came out of Lisbon, showed all their insufficiency. This was the first cause, on the one hand, for a flight from the Treaties and the community method, towards intergovernmental instruments, such as the European Stability Mechanism (ESM) and the Fiscal Compact (2012) ${ }^{22}$, and, on the other, for the implementation of the macroeconomic surveillance system on the budgets of the Member States, which caused the growth of the asymmetry between the Member States and the net loss of wealth. In fact, it has been calculated that this policy, known as "Austerity", for each consolidated euro, resulted in a drop in GDP equal to two euro ${ }^{23}$.

If Europe has not collapsed and, above all, if its currency, the euro, has been able to keep the markets at bay, it is due to the action of the European Central Bank, which - even in contrast to the opinion of some governments of Member States, including Germany - countered market speculation that caused a spike in yields and spreads on government bonds, and deployed important monetary operations to defuse speculation, such as rate cuts and the purchase plan of government bonds on the markets (Quantitative Easing). In addition, the ECB has determined expansionary budgetary policies and the refinancing of banks to counter the credit crunch caused by the crisis, accompanying the weak recovery over time and keeping inflation under strict control ${ }^{24}$.

22 See B. DE WITTE, 2011, n. 6; A. DE GREGORIO MERINO, 2012, 1634; K. LENAERTS, 2014, 758; A. DIMOPOULOS, 2014, 59; P. CRAIG, 2012, 231 ss,; L.S. ROSSI, 2012, 297; G.L. TOSATO, 2012, 15; J.C. PIRIS, 2012; B. DE WITTE, A. OTT, E. VOS (Eds), 2018.

23 See MULTIPLE AUTHORS, 2013; L. BINI SMAGHI, 2013; K. BUSCH, C. HERMANN, K. HINRICHS, T. SCHULTEN, 2013; D. GROS, 2012, 3, 175; R. MAURER, 2012, 3, 177.

24 When the tension on the financial markets had reached a real climax and it was feared that the Greek crisis could threaten the very survival of the euro, the President of the ECB, Mario Draghi, in his speech to the Economic and Monetary Affairs Commission of the 


\section{THE EUROPEAN UNION AFTER THE ECONOMIC AND FINANCIAL CRISIS}

With the waning of the economic and financial crisis, the condition of the European Union did not improve in the same way as did in other areas of the world and this seemed to be essentially and once again attributable to its scarce ability to carry out a real economic policy. From this point of view, the confrontation with the United States is merciless. Suffice it to say that the Obama administration with the Recovery and Reinvestment Act and the

European Parliament, on 19 December 2011, declared the irreversibility of the Euro and expressed the position that, although the ECB does not have the function of "lender of last resort", since "the EU Treaty prohibits monetary finance", "there is no limit" to the purchase of government bonds on the secondary market to facilitate the transmission of monetary policy decisions; even if he added immediately after that "the program would not (would have been) eternal and not (would have been) infinite". This position aroused strong criticism, especially from the German side (at least until the German Chancellor Angela Merkel's declaration of support for the Draghi line). Subsequently, the president of the ECB himself reiterated this affirmation in London, on the occasion of the meeting at the Global Investment Conference, on 26 July 2012. In fact, during this meeting, in addition to the irreversibility of the euro, he underlined how the yields of sovereign bonds that have dealing with the danger of default, with liquidity and "even more and more with convertibility, with the risk of convertibility", fall within the mandate of the ECB and are within its competence. Consequently, "to the extent that the size of these sovereign debt yields hampers the functioning of monetary policy transmission channels, they fall within our [i.e. the ECB's] mandate." In that conference the famous sentence was also pronounced: "Within our mandate, the ECB is ready to do whatever it takes to preserve the euro. And believe me, it will be enough". Thanks to this position, the Governing Council of the ECB on 2 August 2012 gained the opportunity to proceed with the activation of the Outright Monetary Transactions (OMT) program (see, on these events, the book by J. RANDOW, A. SPECIALE, 2019) 


\section{Mangiameli ICOVID-19 AND EUROPEAN UNIONI ISSN 2675-1038}

support of the Federal Reserve had been able to implement measures for 787 billion dollars already at the beginning of $2009 .{ }^{25}$

The governments of the Member States of the European Union, although they were aware that the limits of joint action within the Economic and Monetary Union were at the basis of the low economic growth and the slow recovery in the old continent, could not find the way for an appropriate change.

The Commission's Blueprint $(2012)^{26}$ and the Five Presidents' report $(2015)^{27}$ identify a series of actions to be implemented such as the banking union and the financial markets union, the reform of own resources and fiscal capacity, as well as the creation of a European Treasury with a real Minister of Finance, to make the Union capable of stemming other shocks in the future.

To the reforms of economic nature, then, they added those of an institutional nature, for which it would have been necessary "to give political direction and increase democratic responsibility", through a corresponding political integration, based on the strengthening of supranational democracy. In this sense, the path of the European reforms should have overcome the intergovernmental tendencies that had manifested themselves during the crisis and arrive at a modification of the treaties. In fact, it would

25 See Executive Office of the President - Council of Economic Advisers, The Economic Impact of the American Recovery and Reinvestment Act of 2009, Second Quarterly Report - January 13, 2010.

26 European Commission, A blueprint for a deep and genuine economic and monetary union. Launching a European Debate, COM(2012) 777 final/2, 30.11.2012.

27 Report by Jean-Claude Juncker, in close cooperation with Donald Tusk, Jeroen Dijsselbloem, Mario Draghi and Martin Schulz, Completing Europe's Economic and Monetary Union. The Report was published on 12 June 2015 and presented at the European Council of June 2015, but the discussion on it was postponed to the European Council meeting in December 2015. 


\section{Mangiameli ICOVID-19 AND EUROPEAN UNIONI ISSN 2675-1038}

be a question of raising "the level of democratic responsibility", which "must remain commensurate with the degree of the transfer of sovereignty from the Member States to the European Union", ${ }^{28}$

However, the time span traced by these projects was so long, that the reform of the treaties and the strengthening of European democracy would have come after 2020 and, subsequently, even after 2025. In this way, neither the European institutions, neither the Member States, nor the European citizens have felt a positive development of the European integration process $^{29}$.

Thus, a Euroscepticism spread in Europe which found its first political representation in the 2014 European Parliament elections.

In addition, over the years other difficulties have been added to those encountered in the attempt to achieve the deepening of the Economic and Monetary Union. In fact, over the last decade the European Union has been plagued by multiple crises, in addition to that of the euro, there have been the long Brexit saga (from 2016 onwards), the refugee crisis, which put into question the area of freedom, security and justice (Art. 61 TFEU) and contributed to the spread of Euroscepticism, and, more recently, to the rise of illiberal governments at the steering of some Member States. The latter, having exercised their power of governance in violation of fundamental rights and the principles of the rule of law, have infringed the values of the European homogeneity clause (Art. 2 TEU).

${ }^{28}$ Report of the five presidents, Completing Europe's Economic and Monetary Union, 20.

${ }^{29}$ See J. HABERMAS, 2013: "The obvious aim is to postpone a revision of the treaties to the very end. The Commission accords the expansion of steering capacities priority in the short and the medium term over a corresponding enlargement of the basis of legitimation. Thus the ultimate democratization is presented as a promise like a light at the end of the tunnel. Supranational democracy remains the declared long term goal on paper'. 
All these difficulties of the path of the integration process are very well represented by the "White Paper on the Future of Europe". In fact, on the 60th anniversary of the Treaties of Rome, in 2017, one could have been wondering along which perspective the European institutions and the Member States were moving. Thus, the European Commission, on the $1^{\text {st }}$ of March 2017, presented its "White Paper on the future of Europe. Reflections and scenarios for the EU27 towards 2025" 30. The White Paper, for the approach followed, gave a very problematic image of the European perspectives, due to the presentation of five different scenarios, some of which gave the impression that the integration process could be limited or even reduced.

The premises contained in the White Paper gave account of the success of the European integration process, in terms of peace, economic development, as well as for the recognition and protection of fundamental rights and respect for the rule of law. In addition, at the same time, this document contextualized the economic indicators, geopolitical and social, stating that "the rapidly rising influence of emerging economies accentuates the need for Europe to speak with one voice and to act with the collective weight of its individual parts". Furthermore, the paper posed the need to look to future generations, to ensure them a prospect of welfare and greater social and territorial equity, to which added "the need to complete the Economic and Monetary Union and to strengthen the convergence of economic and social developments". Finally, it referred to the aim of modernizing social protection systems and ensuring environmental protection based on the decarbonization of the European economy, the efficient use of natural resources and the fight against climate change.

However, the Paper was also based on "a growing disaffection with mainstream politics and institutions at all levels (...) easily filled by populist

${ }^{30}$ European Commission COM(2017)2025 of 1 March 2017. 


\section{Mangiameli ICOVID-19 AND EUROPEAN UNIONI ISSN 2675-1038}

and nationalist rhetoric" and the presence of "stark images of disunity". In fact, it indicated the reasons why the European design seems to have been affected by mistrust and the questioning of legitimacy and observed: "There is still strong support for the European project, but it is no longer unconditional". In this regard, the paper notes that "Closing the gap between promise and delivery is a continuous challenge", which suffers from the "mismatch between expectations and the EU's capacity to meet them". In particular, this condition depends on two very specific circumstances: on the one hand, the competences, for which "the tools and powers remain in the hands of national, regional and local authorities"; and, on the other hand, the "Resources available at European level", which in the absence of European taxation are on many occasions non-existent.

The titles of the five scenarios, apart from the one that bears the heading "Doing much more together", indicate paths that modify the idea of the integration process, at least in the terms so far always indicated by the majority of scholars of the European institutions. In fact, starting from the maintenance of the status quo ("Carrying on"), passing to the other scenarios - "Nothing but the single market", "Those who want more do more" and "Doing less more efficiently" -, these seem to oscillate between a condition of unease such as that determined by austerity, to one in which the political dimension of the European process is lost. In this way the European order seems to open up to forms of asymmetry greater than those already in existence, with the consequence of increasing gaps between European citizens and the various territories.

Overall, one gets the impression that the White Paper on the future of Europe had an almost provocative character and the design of the five scenarios was done in order to push the Heads of State and Government to choose the most challenging scenario (Doing a lot of more together). In this regard, the White Paper outlined a work program for the Commission, up to the election of the European Parliament in 2019. This program included, in addition to common defence, reflections on EMU and EU finances, and 
also the evolution of the social dimension of Europe, which should lead to the construction of the social pillar ${ }^{31}$.

\section{THE 2019 PARLIAMENTARY ELECTIONS, THE VON DER LEYEN COMMISSION AND THE REVIEW OF THE ESM TREAT}

The European Union went to the vote for the European Parliament in 2019 with a particularly problematic situation from an economic point of view, tired at heart and with deep divisions between the Member States. Even the internal condition of the Member States themselves was by no means simple: European principles were questioned everywhere and, with them, even the principles of democracy and fundamental rights. Nationalistic visions and authoritarian visions reinforced each other, in the European Parliament and in the national parliaments, influencing the governments of the Member States and even conquering some of them.

The result of the ballot boxes, however, did not fully reward these positions and, in any case, not sufficiently to completely overturn the European prospects.

However, the major political parties of European tradition (the popular and the socialist one) were faced with the problem of how to conduct the integration process after this long period of crisis, in which the European Union has continually oscillated between receding to the condition of a container of Sovereign states of a free trade area and progress towards an

${ }^{31}$ See: The Rome Declaration ("Declaration of the leaders of 27 Member States and of the European Council, the European Parliament and the European Commission") was published by the Institutions that signed it: see European Council and Council of the European Union, Statements and Remarks, 149/17, 25/03/2017; European Commission, Statement 17/767, 25 March 2017. 


\section{Mangiameli ICOVID-19 AND EUROPEAN UNIONI ISSN 2675-1038}

Entity with a strong political character on the international scene and organized internally according to the principles of democracy, federalism, fundamental rights and the rule of law.

The program of the Commission chaired by Ursula von der Leyen, although it shows a certain political ambition, has tried to synthesize these two trends without completely resolving them and, therefore, lacks a decisive push in favour of the European integration process ${ }^{32}$. Also in the implementation of the work program of the current Commission, presented in January $2020^{33}$, the political aspect of integration, namely: democracy and the federalization of relations with Member States - as had already happened with the 2012 Blueprint and the report of the five Presidents of 2015 - is placed at the end in an imprecise time horizon and, now, it runs the risk once again of being overwhelmed by subsequent events such as the Covid19 pandemic.

It should be remembered that in a favourable situation, such as the one that preceded the economic crisis, interdependence between Member States is a source of greater prosperity, while in the most difficult periods, such as those of the crisis, it involves greater sharing of the risks that it must be accompanied by a shared responsibility. This sharing can only be responsible if it is capable of producing a political decision appropriate to economic recovery and growth; otherwise sharing - as happened with the austerity policy - translates into a major depression with no outlets and,

32 The Political Guidelines focus on six headline ambitions for Europe over the next five years and well beyond: - A European Green Deal; - An economy that works for people; A Europe fit for the digital age; - Protecting our European way of life; - A stronger Europe in the world; - A new push for European democracy (U. von DER LEYEN, 2019).

33 Communication from the Commission to the European Parliament, the Council, the European economic and social Committee and the Committee of the Regions, Commission Work Programme 2020, A Union that strives for more, of 29.1.2020 COM(2020) 37 final. 


\section{Mangiameli ICOVID-19 AND EUROPEAN UNIONI ISSN 2675-1038}

therefore, from the institutional point of view, capable of undermining trust in common institutions.

The signs of this political fragility have already emerged and the theme that returns to the debate, also to tackle the Covid-19 pandemic, is that of a closer political union between the Member States of the EU and, in particular, of the Eurozone. In other words, the issues are two: the distribution of political decision-making power between the institutions and the Member States and that between the institutions themselves: in a word, the question of European federalism and the question of European democracy, which are waiting to receive an adequate response that does not seem postponable to an indefinite future.

In this sense, the sequence of events concerning the Treaty on the European Stability Mechanism is symptomatic, with the conclusion reached in the meeting of the Eurogroup on 30 November 2020, in which the ministers agreed to proceed with the signing of the revised Treaty in January 2021 and to launch the ratification process ${ }^{34}$. In fact, born as a result of intergovernmental collaboration outside the European treaties, the Commission had also proposed on the recommendation of the Presidents of the European institutions to proceed towards the incorporation of this into the EU legal system. In this perspective, the ESM should have become the European Monetary Fund, which would have allowed the EU to overcome other crises and to strengthen the Economic and Monetary Union, especially with reference to the Banking Union and that of the capital markets.

${ }^{34}$ See the Press Release, Statement of the Eurogroup in inclusive format on the ESM reform and the early introduction of the backstop to the Single Resolution Fund, 839/20 3011.2020. See also the Letter of the Eurogroup President, Pascal Donohoe, to the President of the European Council, Charles Michel, of 4 December 2020 and the Statement of the Euro Summit meeting, 11 December 2020, EURO 502/20. 


\section{Mangiameli ICOVID-19 AND EUROPEAN UNIONI ISSN 2675-1038}

Instead, despite the Commission's proposal to that effect, in 2017, the European Council, in its capacity as a Euro Summit, and the Council in its capacity as Eurogroup in June 2019, decided to maintain the current ESM structure as an intergovernmental agreement, giving it greater powers, also relating to the banking union, and providing for more stringent conditionality requirements for any interventions in favour of Member States in difficulty ${ }^{35}$.

Indeed, the ESM revision treaty will determine - at best - the maintenance of the current fragmentation of powers between the community sphere and the intergovernmental sphere. The signing and ratification of it, therefore, will not lead to greater institutional transparency of the European system. If we consider, then, that this treaty, like that of 2012, also affects the issue of the distribution of joint decision-making power among the Member States, it is clear that its approval could accentuate the asymmetry between governments in the exercise of this joint decision-making power and not to improve the quality of relations between Member States, both in terms of solidarity and in building a common European horizon. In fact, it is known that such treaties determine a transfer of sovereignty, without making it clear who actually manages the shares of political power conferred by the States with similar Agreements ${ }^{36}$.

\section{THE EU RESPONSE TO THE COVID-19 PANDEMIC AND THE NEW 2021-2027 MFF}

Now, despite the aporias highlighted in the evolution of the European Union over the last decade, the Covid-19 pandemic has made it clear that the health crisis cannot be overcome without a joint and solidary

${ }^{35}$ Letter of the Eurogroup President to the President of the Euro Summit, of 15 June 2019.

36 See S. MANGIAMELI, 2017, 189-216. 
contribution from European institutions and Member States. In fact, when the epidemic appeared in Europe - after an initial brief general disorientation -, all the European institutions reacted by revising the EU economic policy guidelines, because the proposed measures required institutional and legislative changes. These changes, on the one hand, should have led to an effective reaction to the economic consequences of the pandemic and, on the other hand, by configuring the pandemic as a symmetrical shock, they should have called into question the very structure of the measures adopted up to that moment to counter economic and financial crisis, starting with budgetary constraints and macroeconomic surveillance.

Therefore, the economic policy decisions taken by the European institutions to counter the economic effects of the pandemic, albeit of a temporary nature, mark a change in the perspectives within which the European Union had moved and highlight the limits and delays with which the same Institutions, and in particular the Council, had proceeded to implement the measures indicated in the Report of the five Presidents.

The first important point of the new course is announced by the ECB on 13 March 2020 with the resumption of quantitative easing, which is immediately boosted from the initial 130 billion to 750 billion in the session between 18 and 19 March with an Outright monetary transactions (OMT) program, called Pandemic emergency purchase program (PEPP) ${ }^{37}$. In this way, the ECB has activated the new securities purchase program for 2020 to face the economic crisis generated by the coronavirus pandemic and to help governments transfer real money to citizens. The principle enunciated by the President of the ECB, Christine Lagarde, is that "Extraordinary times

37 See Press Release of 18 March 2020 when ECB announced €750 billion Pandemic Emergency Purchase Programme (PEPP), 


\section{Mangiameli ICOVID-19 AND EUROPEAN UNIONI ISSN 2675-1038}

require extraordinary actions", so "There are no limits to our commitment to the euro" 38 .

This was accompanied by a specific European economic policy, defined thanks to the collaboration between the European institutions, to combat Covid-19, starting from 13 March 2020, when the Commission put forward the proposal to use the "General safeguard clause" in the framework of the Stability and Growth Pact (i), together with related measures such as a coordinated use against the pandemic of structural funds and "state aid". Then there is the creation of three safety nets: the establishment of a Support to mitigate Unemployment Risks in an Emergency (SURE), for an amount of approximately 100 billion (ii), the use of the MES with a credit line for direct and indirect expenditure on health, defined in coordination with European institutions and called Pandemic Crisis Support (iii), and the EIB Group's initiative to create a Pan-European Guarantee Fund (EGF) of EUR 25 billion, which could support $€ 200$ billion in business finance with a focus on SMEs across the EU (iv). In addition, the European institutions have deemed necessary to prepare a particular Recovery fund, with the evocative name of "Next Generation EU" (v). The connection of the measures related to the Recovery fund would be given by the strengthened and updated European Union budget for the period 2021-2027 (vi).

(i) With reference to the activation of the "general safeguard clause of the Stability and Growth Pact", whose legal basis lies in the regulations of the Six Pact ${ }^{39}$, the Commission started from the assumption that the decline in

${ }^{38}$ ECB president Christine Lagarde said on Twitter of 19 March 2020.

39 Precisely in the Regulations n. 1466/97 (As amending by the Regulation (EU) No 1175/2011 of the European Parliament and of the Council, of 16 November 2011; see Art. 5, para. 1, last subsection) and n. 1467/97 (As amending by the Council Regulation (EU) No 1177/2011 of 8 November 2011; see Art. 3, para. 5). 


\section{Mangiameli ICOVID-19 AND EUROPEAN UNIONI ISSN 2675-1038}

economic activity in 2020, due to the pandemic Covid-19, could be compared to the contraction of 2009 , the worst year of the economic and financial crisis. Moreover, the Commission also considered that Member States had adopted and were still taking fiscal measures and further measures, to increase the capacity of health systems and to support particularly affected citizens and sectors, whose effects, together with the decline in economic activity, would have contributed to substantially increase budget deficits ${ }^{40}$.

The Commission also considered that the budgetary flexibility provided for in the Stability and Growth Pact would not be sufficient for this purpose, but that the use of greater flexibility under the Stability and Growth Pact would be necessary.

Hence, the use of the provision of the Stability Pact relating to unusual events, both because the crisis is an event beyond the control of public administrations with significant repercussions on public finances, and because the size of the budgetary effort necessary to protect the European citizens and businesses from the consequences of this crisis and to support the economy after the pandemic required the use of greater flexibility. This would imply that the budgetary impact of measures taken to counter the pandemic should be ruled out when the Commission would assess compliance with the Stability and Growth Pact. In fact, it is good to warn that the general safeguard clause does not suspend the procedures of the Stability and Growth Pact; it simply allows the Commission and the Council

40 See Communication from the Commission to the European Parliament, the European Council, the Council, the European Central Bank, the European Investment Bank and the Eurogroup, Coordinated economic response to the COVID-19 Outbreak, of 13.3.2020, $\operatorname{COM}(2020) 112$ final, page 11; and also Communication from the Commission to the Council on the activation of the general escape clause of the Stability and Growth Pact, of 20.3.2020, $\operatorname{COM}(2020) 123$ final. 


\section{Mangiameli ICOVID-19 AND EUROPEAN UNIONI ISSN 2675-1038}

to take the necessary policy coordination measures under the Pact, departing from the budgetary obligations that would normally apply. ${ }^{41}$

(ii) As announced in the Communication of 13 March 2020, the Commission, to alleviate the impact of the pandemic on employment for the people and sectors most affected, proposed to the Council, on 2 April 2020, a new instrument for temporary Support to mitigate Unemployment Risks in an Emergency (SURE), which represents one of the three safety nets and allows Union financial assistance of up to EUR 100 billion in the form of Union loans to the Member States concerned ${ }^{42}$.

The Council formalized the proposal on May $19^{\text {th }}, 2020^{43}$. The regulation has its legal basis in art. 122, para. 2, TFEU, which allows the Council to grant Union financial assistance to a Member State that is in difficulty or is seriously threatened by serious difficulties due to exceptional circumstances beyond its control.

The SURE instrument would complement the national measures taken by affected Member States, providing financial assistance, to mitigate the direct economic, social and health effects of the exceptional event caused by the Covid-19 pandemic.

${ }^{41}$ S. HAUPTMEIER, N. LEINER-KILLINGER, 2020, 5, 296-300.

42 See Communication from the Commission to the European Parliament, the European Council, the Council, the European Central Bank, the European Investment Bank and the Eurogroup, Coordinated economic response to the COVID-19 Outbreak, of 13.3.2020, $\operatorname{COM}(2020) 112$ final; see also European Commission, Proposal for a Council Regulation on the establishment of a European instrument for temporary support to mitigate unemployment risks in an emergency (SURE) following the COVID-19 outbreak, 2.4.2020, COM(2020) 139 final

${ }^{43}$ Council Regulation (EU) 2020/672 of 19 May 2020 on the establishment of a European instrument for temporary support to mitigate unemployment risks in an emergency (SURE) following the COVID-19 outbreak 


\section{Mangiameli ICOVID-19 AND EUROPEAN UNIONI ISSN 2675-1038}

A Member State can request Union financial assistance under this facility if its actual and possibly even planned public expenditure has suddenly and severely increased since 1 February 2020 due to national measures directly linked to work programs, reduced hours and similar measures to address the economic effects of exceptional events caused by the Covid-19 pandemic.

Financial assistance takes the form of a loan granted by the Union to the Member State concerned.

The constitution of SURE was an expression of the solidarity of the Union, pursuant to art. 122, par. 1, TFEU, under which Member States agree to mutually support each other through the Union by making additional financial resources available through loans, in accordance with the provisions of art. 122, par. 2, TFEU.

In particular, in the case of this instrument, against the guarantees offered by the Member States in favour of the Union, the resources are offered on loan directly from the European level with the issuing of particular bonds (social bonds) and with direct commitment of the European budget. Consequently, it can be said that the financial assistance offered by the SURE constitutes a real economic and social policy practiced at European level, to temporarily protect the productive capacity and human capital of the Member States, that does not require countermeasures to the assisted State Member and can be particularly useful in dealing with the second wave of the Covid-19 pandemic. $^{44}$

The activation of the Support to mitigate Unemployment Risks in an Emergency took place at the end of September 2020, following the completion of the national approval procedures and the signature by all Member States of the guarantee agreements with the Commission in

${ }^{44}$ K. CROONENBORGHS, 2020, May 30, 1. 


\section{Mangiameli ICOVID-19 AND EUROPEAN UNIONI ISSN 2675-1038}

accordance with the Regulation and the decision of the Council to offer financial assistance to 18 Member States under the facility, to protect jobs and employment. In fact, on 7 October 2020 the European Commission announced that it would issue its forthcoming EU SURE bonds as social bonds $^{45}$ and made known EU SURE Social Bond Framework ${ }^{46}$, which is a document which will enable the Commission to issue its SURE bonds worth up to $€ 100$ billion $^{47}$; and on October 21, the European Commission has effectively issued share inaugural bond for 17 billion euro. On 27 October, the EU SURE social bond was listed on the Luxembourg Stock Exchange.

The period of availability of the instrument during which a decision referred to in Article 6 (1) of the Regulation can be adopted ends on 31 December 2022. However, it is quite possible that, once the pandemic has passed, this instrument may remain in the European legal system.

(iii) In the video conference of 23 April 2020 the European Council approved the agreement reached by the Eurogroup on the ESM instrument, to establish a Pandemic Crisis Support (PCS), which would represent a specific safety net for Member States of the euro area ${ }^{48}$.

45 European Commission to issue EU SURE bonds of up to $€ 100$ billion as social bonds, Press Release, 7 October 2020.

46 European Commission, EU SURE Social Bond Framework, 7 October 2020, (https://ec.europa.eu/info/sites/info/files/about_the_european_commission/eu_budge t/eu_sure_social_bond_framework.pdf)

${ }^{47}$ European Commission, Questions and Answers: European Commission to issue EU SURE bonds of up to $€ 100$ billion as social bonds, 7 October 2020.

48 See Conclusions of the President of the European Council following the video conference of the members of the European Council, 23 April 2020, Statements and Remarks, 251/20, 23/04/2020. 


\section{Mangiameli ICOVID-19 AND EUROPEAN UNIONI ISSN 2675-1038}

The prerequisite for the use of ESM funds would lie in the circumstance that, in the euro area, the ESM would be equipped with tools that could be used, if necessary, in a manner adapted to the nature of the symmetrical shock caused by Covid-19. In particular, it was deemed possible to base support for the pandemic crisis on the existing precautionary ECCL (enhanced conditions credit line), adapting it to this specific challenge. Indeed, it is assumed that the only requirement to access the credit line is that the euro area Member States requesting the support undertake to use this credit line for the domestic financing of direct and indirect healthcare, cure and prevention related costs due to the Covid-19 crisis. The total amount of credit that would be granted would be equal to $2 \%$ of the GDP of the respective Member State, taking the end of 2019 as a benchmark. The credit line should be available until the end of the Covid-19 crisis ${ }^{49}$.

(iv) In its report of 9 April 2020, the Eurogroup welcomed the EIB Group's initiative to create a Pan-European Guarantee Fund (EGF) of EUR 25 billion, which could support EUR 200 billion in business finance with a focus on SMEs across the EU through national promotional banks ${ }^{50}$. The Eurogroup called on the EIB to make its proposal operational as soon as possible and to be ready to implement it without delay, ensuring complementarity with other EU initiatives and with the future Invest-EU program.

49 Summing up letter of the Eurogroup President, to the members of Eurogroup in inclusive format, on Eurogroup in inclusive format of 7-9 April 2020, 17 April 2020, ecfin.cef.cpe(2020)2329436, Report by the Eurogroup, in inclusive format, on the comprehensive economic policy response to the COVID-19 pandemic, 5/6.

50 Eurogroup in inclusive format of 7-9 April 2020, 17 April 2020, ecfin.cef.cpe(2020)2329436, Report by the Eurogroup, in inclusive format, on the comprehensive economic policy response to the COVID-19 pandemic, 5/6, point 15. 
The EGF is also part of the global package of measures approved by the European Council on 23 April 2020 and constitutes a safety net for businesses and, in particular, SMEs ${ }^{51}$. The EGF is an important contribution to maintaining a level playing field in the single market in the light of national support schemes. The objective of the European Guarantee Fund is in fact to respond to the economic impact of the Covid-19 pandemic, guaranteeing the companies of the participating Member States sufficient liquidity in the short term, to resist the crisis and be able to continue their growth and development in the medium and long term. The European Guarantee Fund requires a contribution from all EU-27 Member States with an expected size of EUR 25 billion and would be managed by the EIB Group, which would aim to generate - as mentioned above - up to EUR 200 billion in additional funding, leveraging on initial resources.

Through the EGF, the European Investment Fund ${ }^{52}$ would distribute a range of equity, debt funds and guarantee products in partnership with selected financial intermediaries for the benefit of SMEs and mid-cap companies $^{53}$.

51 See Conclusions of the President of the European Council following the video conference of the members of the European Council, 23 April 2020, Statements and Remarks, 251/20, 23/04/2020.

52 The European Investment Fund (EIF) is a specialist provider of risk finance to benefit small and medium-sized enterprises (SME) across Europe, which is part of the EIB Group. More than 1 million SMEs have benefited from enhanced access to finance through financial instruments managed by EIF.

${ }^{53}$ In particular, as regards the products guaranteed by the EGF, they can be: a) Guarantees and Securitization products: public or private entities (including credit or financial institutions or loan (debt) funds), if applicable, duly authorized to carry out debt financing activities according to the applicable legislation; b) Counter-Guarantees: public or private (counter-) guarantee schemes, (counter-) guarantee institutions or other entities, credit or financial institutions, if applicable, duly authorized to issue guarantees according to the applicable legislation. 
The deadline for submitting applications is currently October 31, 2021; although this deadline may be brought forward or postponed, depending on the availability of budgetary resources for the EGF.

(v) From various points of view, the most challenging instrument to counter the economic effects of the pandemic and immediately prepare the relaunch of the European economy, projecting it towards unprecedented investments in the green and digital strategy, is the "Recovery fund- Next Generation EU"54.

The principles of the Recovery fund would be as follows: a) the EU Recovery plan must be based on solidarity, cohesion and convergence; b) the approach to this recovery must therefore be flexible and agile and must evolve over time; c) the Recovery plan must be inclusive and jointly owned by all parties involved (from EU Institutions to Member States, regions, businesses, civil society, social partners and other stakeholders); d) the fund must be disbursed in compliance with the values on which the EU is founded and the protection of fundamental rights, to ensure the integrity of our model and our lifestyle.

${ }^{54}$ The first formulation of the recovery fund is found in the Joint statement of the Members of the European Council, of 26 March 2020 (https://www.consilium.europa.eu/media/43076/26-vc-euco-statement-en.pdf) and in the European Parliament resolution of 17 April 2020 on EU coordinated action to combat the COVID-19 pandemic and its consequences (2020/2616(RSP)) P9_TAPROV(2020)0054. Immediately afterwards the President of the European Council and the President of the Commission drew up $A$ roadmap for recovery - Towards a more resilient, $\begin{array}{lllll}\text { sustainable } \text { and } & \text { Eair } & \text { Europe, }\end{array}$ (https://www.consilium.europa.eu/media/43384/roadmap-for-recovery-final-21-042020.pdf), which was based on four principles and four key areas for action. 


\section{Mangiameli ICOVID-19 AND EUROPEAN UNIONI ISSN 2675-1038}

The four key areas of action would be expressed by: a fully functioning and revitalized single market; an unprecedented investment effort; global action; and a functioning governance system.

The proposal for the Recovery fund, which has received repeated approval over time, from the European Council (23 April 2020) and the Eurogroup (7-9 April and 14 May 2020), was presented by the Commission with the Communication of 27 May 2020, with the significant title: "Europe's time: repair and prepare for the next generation" 55 . The European Council at its extraordinary meeting in July 2020 endorsed the Commission communication authorizing the Commission to borrow funds, on behalf of the European Union, on the capital markets, and to transfer the proceeds to Union programs in accordance with Next Generation EU ${ }^{56}$.

Ultimately, this plan would not only be considered as an economic plan, but as a project with a very important political significance, as it would also strive for a recovery based on EU values and fundamental rights, including social rights, and to ensure a stronger presence of Europe in the world. In particular, Next Generation EU is expected to be a new $€ 750$ billion recovery instrument, integrated into a more powerful and modern longterm EU budget, not least because the funds raised should be repaid through future EU budgets, not before 2028 and not after 2058.

The borrowed funds can be used for loans up to $€ 360$ billion and grants up to $€ 390$ billion and the amounts owed by the Union in any given year for the repayment of the principal do not exceed $7,5 \%$ of the maximum amount

55 The Commission would have presented proposals in this respect and did so with the Communication from the Commission to the European Parliament, the European Council, the Council, the European Economic and Social Committee and the Committee of the Regions, Europe's moment: Repair and Prepare for the Next Generation, of 27.5.2020, COM(2020) 456 final.

${ }^{56}$ European Council, Special meeting of the 17, 18, 19, 20 and 21 July 2020 - Conclusions, 21 July 2020, EUCO 10/20, point A3. 


\section{Mangiameli ICOVID-19 AND EUROPEAN UNIONI ISSN 2675-1038}

of 390 billion euros for grants ${ }^{57}$. Legal commitments of a program completed by the NGEU will be made by 31 December 2023 and related payments will be made by 31 December 2026.

The European Council has foreseen that the amounts of NGEUs for the individual programs are as follows: the Recovery and Resilience Facility (RRF) $€ 672.5$ billion, of which loans $€ 360$ billion and grants $€ 312.5$ billion; React-EU (cohesion policy): $€ 47.5$ billion; Horizon Europe (research and development policy): $€ 5$ billion; Invest-EU (an investment program for Europe, based on the successful model of the Juncker Plan): EUR 5.6 billion; Rural development (the CAP funding instrument that supports rural development strategies and projects): $€ 7.5$ billion; Just Transition Fund (JTF) (the first pillar of the Just Transition Mechanism): EUR 10 billion; Resc-EU (a new European reserve of resources in the context of the EU civil protection mechanism): $€ 1.9$ billion; for a total of 750 billion euros. ${ }^{58}$

Member States prepare national recovery and resilience plans which define the reform and investment program of the Member State concerned for the years 2021-23. The plans will be reviewed and adapted, if necessary, in 2022 to take into account the final allocation of funds for 2023. ${ }^{59}$

Member States' recovery and resilience plans are assessed by the Commission within two months of submission. The consistency criteria with the country-specific recommendations, as well as the strengthening of the growth potential, job creation and economic and social resilience of the Member State require the highest score of the assessment. An effective

${ }^{57}$ European Council, Special meeting of the 17, 18, 19, 20 and 21 July 2020 - Conclusions, 21 July 2020, EUCO 10/20, point A8.

${ }^{58}$ European Council, Special meeting of the 17, 18, 19, 20 and 21 July 2020 - Conclusions, 21 July 2020, EUCO 10/20, point A14.

${ }^{59}$ European Council, Special meeting of the 17, 18, 19, 20 and 21 July 2020 - Conclusions, 21 July 2020, EUCO 10/20, point A18. 


\section{Mangiameli ICOVID-19 AND EUROPEAN UNIONI ISSN 2675-1038}

contribution to the green and digital transition will also be a prerequisite for a positive assessment ${ }^{60}$.

The assessment of recovery and resilience plans is approved by the Council, by qualified majority on a proposal from the Commission, by means of an implementing act which the Council endeavors to adopt within 4 weeks of the proposal.

The positive evaluation of payment requests will be conditional on satisfactory compliance with the relevant milestones and objectives ${ }^{61}$.

In this respect, the Commission should seek the opinion of the Economic and Financial Committee on the satisfactory achievement of the relevant milestones and objectives. The Commission takes a decision on the assessment of satisfactory compliance with the relevant milestones and objectives and on the approval of payments in accordance with the examination procedure ${ }^{62}$.

(vi) Well before the start of the pandemic, the Commission had highlighted the need to review budget discipline in view of the MFF for the period 20212027. When in July 2020, after the decision of the European Council, the discussion on the Recovery fund was opened, this was immediately linked to the EU budget, in the sense that the fund would be managed through the budget - with the community method and with the participation of the European Parliament - and in connection with the implementation of green

${ }^{60}$ See C. Binet, 2020, no. 269, 207-211; M. Elkerbout, C. Egenhofer, J. Núñez Ferrer, M. Catuti, I. Kustova, V. Rizos, 2020, n. 6.

${ }^{61}$ European Council, Special meeting of the 17, 18, 19, 20 and 21 July 2020 - Conclusions, 21 July 2020, EUCO 10/20, point A19.

${ }^{62}$ European Council, Special meeting of the 17, 18, 19, 20 and 21 July 2020 - Conclusions, 21 July 2020, EUCO 10/20, point A19. 


\section{Mangiameli ICOVID-19 AND EUROPEAN UNIONI ISSN 2675-1038}

and digital transitions and the other of the six priorities designed by the Commission, according to its strategy (2020-2030) ${ }^{63}$.

In particular, it was the merit of the European Parliament, through a resolution, to have highlighted the criticalities of the budget and of the Next Generation EU project itself. ${ }^{64}$

Negotiations between Parliament and Council were not easy, if only at the beginning of November a preliminary political agreement was reached on the MFF 2021-2027, with which Next Generation EU was closely associated. In this context, a not secondary aspect are the proposals to concretely increase the EU budget, for which the European Council has foreseen an increase of $0.6 \%$ in the amounts of the ceilings of own resources. The agreement reached with the EP would include an addition of 16 billion to the EU budget, which would come mainly from the amounts corresponding to the fines on competition; and 15 billion of these would serve to strengthen the flagship programs, which risked being underfunded under the agreement between the governments of the Member States at the European Council in July. ${ }^{65}$

Furthermore, another aspect of the agreement reached with the EP concerned the acceptance of the principle according to which the medium and long-term costs of repaying the debt that would derive from the Recovery Fund must derive from new own resources, the forecast of which was carried out according to a roadmap linked to the agreement itself. In

${ }^{63}$ The amount of the MFF, including the NGEU, would have reached the sum of $1.824,300$ billion euros. See the Multiannual Financial Framework 2021-2027 And Next Generation Eu (Commitments, in 2018 prices), attached to the Press Release, Multiannual financial framework for 2021-2027 adopted, 969/20, 17/12/2020.

${ }^{64}$ European Parliament resolution of 23 July 2020 on the conclusions of the extraordinary European Council meeting of 17-21 July 2020 (2020/2732(RSP)).

65 See European Parliament, Compromise on long-term EU budget: EP obtains $€ 16$ billion more for key programmes, Press release, 10-11-2020 - 16:17, 20201106 IPR91014 


\section{Mangiameli ICOVID-19 AND EUROPEAN UNIONI ISSN 2675-1038}

particular, the proposals on the new own resources would concern: - a new own resource based on non-recycled plastic waste, which will be introduced and will apply starting from 1 January 2021; - a carbon border adjustment mechanism and digital levy, to be introduced by 1 January 2023; - a revised Emissions Trading System (ETS), possibly extending it to air and sea transport; - a tax on financial transactions. The proceeds from the new own resources introduced after 2021 will be used for the early repayment of the NGEU loans.

Finally, as regards the expenditure of EU funds, Parliament has ensured that the three institutions will meet regularly to evaluate the implementation of the funds put in. Spending will be done in a transparent way and Parliament, together with the Council, will monitor any deviations from previously agreed national plans. In this way, since the Next Generation EU instrument is based on art. 122 TFEU, which provides no role for the European Parliament, the EP negotiators have obtained a new procedure, establishing a "constructive dialogue" with the Council, based on an assessment by the Commission, in order to agree on the budgetary implications of any new act proposed on the basis of Article 122.

\section{THE EVALUATION OF THE INSTRUMENTS TO COMBAT THE COVID-19 PANDEMIC}

It is clear that the initiatives implemented by the European Union to counter the economic effects of the Covid-19 pandemic from the point of view of financial commitment are unparalleled in previous history. If you add up the different funds and budget available, you get to more than three trillion euros. This does not mean that these instruments are not carriers of specific problems and, above all, that they have solved the political problems which, starting from the events of the economic crisis, have plagued the European 


\section{Mangiameli ICOVID-19 AND EUROPEAN UNIONI ISSN 2675-1038}

system, the internal market, the four freedoms, the area of freedom, security and justice, etc. ${ }^{66}$.

The measures to combat the Covid-19 pandemic, even if they were to have maximum effectiveness, would still not have the capacity to determine by themselves an effective resumption of the European integration process; indeed, in many cases the provisional nature of the adopted measures suggests future problems.

Thus, the general safeguard clause, which allows Member States to deviate significantly from budgetary balances, once the pandemic is over and the constraints of the Stability and Growth Pact are restored, with all the paraphernalia of macroeconomic surveillance, will probably find the Member States in a condition of accentuated asymmetry; except to hypothesize a restructuring of the debt, rather than of the national production systems, through the Recovery fund. However, this would mean that important resources would have been subtracted from investments in the green deal, digitalization, the circular and sustainable economy, energy autonomy, etc.

Even the supports deriving from the SURE, which constitute a first form of debt sharing, thanks to the issue of Eurobonds, do not escape the limits deriving from the temporary nature of the instrument and in any case constitute, for the Member State, a debt that must be repaid.

As for the availability of ESM funds for health purposes, this has not met with the favor of the Member States so far. It is easy to hypothesize that the

${ }^{66}$ It is certainly early to consider the hypothesis of the remission of the debt caused by the Covid-19 pandemic, which would require a change in the treaties. However, it should be noted that a discussion to this effect has been opened by the President of the European Parliament (David Sassoli, Twitter 15 November 2020) and this will certainly be resumed later when the pandemic is tamed and it will be possible to actually calculate the impact it could have on the European recovery. 


\section{Mangiameli ICOVID-19 AND EUROPEAN UNIONI ISSN 2675-1038}

most evident reasons lie in the "stigma" that the ESM carries with it, that is, the use of the Mechanism would imply for the Member State the declaration of a, if not inability, at least difficulty in recovering financial resources in the capital market, making precarious the condition of the public debt of that State.

As regards the terms of the loan, then, these were very imprecise and even after the letter from Vice President Dombrovskis and Commissioner Gentiloni, on the legal aspects of surveillance and conditionalities, several doubts remain ${ }^{67}$. In fact, even if the conditionality linked to Pandemic Crisis Support has been defined as "light", as the assisted Member States should use the funds to "support the domestic financing of direct and indirect healthcare, cure and prevention related costs due to the Covid-19 crisis", Member States would remain committed, for the future, to "strengthen economic and financial fundamentals, in line with the EU economic and fiscal coordination and surveillance frameworks, including any flexibility applied by the competent EU institutions" "68; moreover, regardless of the rules of the ESM Treaty that should also apply in this light conditionality, the fact remains that - as the president of the Eurogroup observed, in his comments to the press - "any euro area country that requires this support remains subject to EU economic and fiscal coordination and surveillance frameworks".

Even the Pan-European Guarantee Fund is not providing the right push for business investment. At the moment, the survey conducted by the EIB itself

${ }^{67}$ European Commission, Letter from Executive Vice-President Dombrovskis and Commissioner Gentiloni to Eurogroup President Centeno clarifying how the Commission intends to carry out surveillance in the framework of the ESM's pandemic crisis support, of 07 May 2020, https://ec.europa.eu/info/sites/info/files/economy-finance/letter_to_peg.pdf 68 See also the "Term sheet: ESM Pandemic Crisis Support" (https://www.consilium.europa.eu/media/44011/20200508-pcs-term-sheet-final.pdf). 
indicates that $43 \%$ of EU companies intend to invest less due to the pandemic and this would be the basis of an estimated decline in investment in the EU between $30 \%$ and 50\%. This shows that the EGF has a very limited role in the dynamics of recovery from the breakdowns of the pandemic crisis and that it appears destined to be complementary to the Recovery fund.

The greatest attraction, therefore, remains for the NGEU Recovery fund, because part of its funds would be given to Member States as grants and not as loans.

As has already been mentioned, the Recovery Fund has been linked to the EU budget and is part of the Multiannual Financial Framework. This led to the fact that the Member States had to respect the principles of the rule of law and the values of the European Union for access to the Recovery Fund as well. Thus, some heads of government (Poland, Hungary), in order to remove all conditionalities, had instructed their permanent representatives to the EU to oppose, in the meeting of 16 November, the decision to start the written procedure for the approval of the EU budget, which requires unanimity.

This conflict between the need for recovery after the pandemic and the principles of the rule of law led to a considerable delay in the development of the NGEU instrument; although, thanks to the intervention of the rotating EU presidency of Germany, it was finally resolved before the meeting of the European Council of 10 and 11 December 2020, in which full consensus was reached on the budget and the $\mathrm{MFF}^{69}$.

In this way, the Council in the meeting of 14 December proceeded to conclude the written procedure, thus approving the financial instruments:

${ }^{69}$ European Council, Meeting of 10, 11 December 2020 - Conclusions, 11 December 2020, EUCO 22/20 


\section{Mangiameli ICOVID-19 AND EUROPEAN UNIONI ISSN 2675-1038}

MFF, EU 2021 budget, Recovery Fund, the own resources decision and the interinstitutional agreement, all the joint and unilateral declarations ${ }^{70}$, plus the Regulation on a general regime of conditionality for the protection of the Union budget ${ }^{71}$.

After the transmission of the relevant documents to the Commission and the European Parliament, the latter at the meeting of 16 December proceeded to express its consent on the MFF, approved the interinstitutional agreement, the joint declarations and the Regulation on a general cross-compliance regime for the protection of the Union budget ${ }^{72}$. The other constitutional procedures are being completed.

\section{THE REACTION TO THE COVID-19 PANDEMIC AND THE FUTURE OF THE EUROPEAN UNION}

The exit from the pandemic appears full of uncertainties, if, in the presence of the first validated vaccines, a third wave is feared, even more serious than the previous ones and destined to further aggravate the economic conditions of the Member States.

The European Union, despite the negotiations carried out by the Commission to acquire vaccines in doses sufficient to satisfy the European

${ }^{70}$ Council of the European Union, Multiannual Financial Framework (MFF) 2021-2027 and Recovery package - End of Written Procedure - Communication of 14 December 2020, CM 5358/20.

${ }^{71}$ Council of the European Union, Position of the Council at first reading with a view to the adoption of a Regulation of the European Parliament and of the Council on a general regime of conditionality for the protection of the Union budget - Statement of the Council's reasons - Adopted on 14 December 2020

72 See European Parliament resolution of 17 December 2020 on the Multiannual Financial Framework 2021-2027, the Interinstitutional Agreement, the EU Recovery Instrument and the Rule of Law Regulation (2020/2923(RSP) 


\section{Mangiameli ICOVID-19 AND EUROPEAN UNIONI ISSN 2675-1038}

request, has shown that it does not have full health independence, both in research, in the devices and in the infrastructures necessary to face the Covid-19 pandemic.

To remedy this situation, the Commission, regardless of the possible use of the ESM by the Member States for health costs, first of all, proposed to allocate 37 billion euros to the Covid-19 emergency within the framework of the cohesion policy for a "Corona Response Investment Initiative" and to fully implement this measure in 2020 through exceptional and accelerated procedures; thus allowing all Member States to redefine priorities and channel aids where it is most needed, including, among other things, supporting the health system.

The Commission therefore proposed to amend the regulations governing the structural funds and the Eurogroup, welcoming it, approved the necessary legislative changes to the regulations governing the structural funds. Two Regulations (EU) $2020 / 460^{73}$ and (UE) $2020 / 558^{74}$ of the European Parliament and of the Council were thus adopted, with which the Union legislator amended the relevant regulatory frameworks, to allow Member States to mobilize all resources not used of the European Structural and Investment Funds, in order to be able to face the exceptional consequences of the Covid-19 pandemic.

${ }^{73}$ Regolamento (UE) 2020/460 del Parlamento europeo e del Consiglio, del 30 marzo 2020, che modifica i regolamenti (UE) n. 1301/2013, (UE) n. 1303/2013 e (UE) n. 508/2014 per quanto riguarda misure specifiche volte a mobilitare gli investimenti nei sistemi sanitari degli Stati membri e in altri settori delle loro economie in risposta all'epidemia di COVID19 (Iniziativa di investimento in risposta al coronavirus).

${ }^{74}$ Regolamento (UE) 2020/558 del Parlamento europeo e del Consiglio, del 23 aprile 2020, che modifica i regolamenti (UE) n. 1301/2013 e (UE) n. 1303/2013 per quanto riguarda misure specifiche volte a fornire flessibilità eccezionale nell'impiego dei fondi strutturali e di investimento europei in risposta all'epidemia di COVID-19. 


\section{Mangiameli ICOVID-19 AND EUROPEAN UNIONI ISSN 2675-1038}

Also, as part of this initiative, the Commission has proposed extending the scope of the EU Solidarity Fund to include public health crises. In this way, another EUR 800 million would be available in 2020 .

Finally, also in the regulation establishing the European instrument for temporary Support to mitigate the risks of unemployment in a state of emergency (SURE), it was envisaged that the financial assistance offered by the instrument also serves to finance certain health measures, in particular in the workplace.

The pandemic, although it is a symmetrical crisis, has accentuated the state of asymmetry of the Member States, even though this gap will emerge more clearly when the pandemic ends.

Above all, however, the pandemic has hit a European Union already afflicted by the economic and financial crisis and with a profound identity crisis, which has not completed the path of the Economic and Monetary Union, which has not yet brought the Fiscal Compact and the ESM back into the framework of European law and which has not definitively resolved the question of internal borders and that of external borders with repercussions on the area of freedom, justice and security and on migration policy.

Even if the pandemic marked a strong resumption of European action, the future of the integration process remains uncertain and the image of the European Union continues to oscillate between the hypothesis of an intergovernmental free trade organization and that of an Association of States with a strong shared sovereignty and its own political, economic and institutional order capable of facing the challenges of globalization under the banner of internal solidarity, among the Member States, and international solidarity, with other Nations. 
If we succeed in convening a new Conference on the Future of Europe, as already assumed by the Commission at the time of its inauguration ${ }^{75}$ and as hoped for in January this year ${ }^{76}$, it is to be hoped that the governments of the Member States will be more adequate and more prompt than they have been in the past and that the European political forces act with a different sentiment from that held up to now.

Also on this occasion, with the pandemic, as in the times of the economic crisis, the shortcomings of the structure of attribution of the EU powers emerged and made the European response difficult and weak; it is enough to think, for example, of the type of competence of the Community institutions in the field of health policy ${ }^{77}$.

On the other hand, the difficulties of the EU and its Member States in adopting a coherent response to the pandemic derive from the imbalance of the institutional structure of the last ten years, towards the intergovernmental logic, rather than towards the Community method, and this it could also harm the effectiveness of the measures implemented by the European institutions in response to the pandemic ${ }^{78}$.

${ }^{75}$ U. von DER LEYEN, 2019, 4.

${ }^{76}$ Communication from the Commission to the European Parliament and the Council, Shaping the Conference on the future of Europe, 22.1.2020, COM(2020) 27 final.

${ }^{77}$ See Art. 4, para. 2, let. K), TFEU ("common safety concerns in public health matters, for the aspects defined in this Treaty"); see also Art. 168 TFEU, on public health. The EU competence on public health is concurrent and very limited ("Union action, which shall complement national policies, shall be directed towards improving public health"). Even though "human health" is present in several provisions of the Treaties and it should take into account "in the definition and implementation of all Union policies and activities", the "public health" in the European Treaties is always the reason to exercise national powers and to limit the European law (see: Articles 36, 45 and 52 TFEU and also Art. 114 TFEU). ${ }^{78}$ See S. MANGIAMELI, 2013, 151-168; S. MANGIAMELI, 2016, 1, 11-58. 


\section{Mangiameli ICOVID-19 AND EUROPEAN UNIONI ISSN 2675-1038}

It is not surprising, therefore, that the European Parliament has expressed itself in favor of the project for a Conference on the Future of Europe, while, on the other hand, the European Council and the Council have shown themselves to be more awaiting ${ }^{79}$.

In conclusion, if it were to come to the organization of a Conference on the Future of Europe, the constitutional mandate should be aimed at a reform of the European Treaties, solving the main structural problems in the EU's relations with the Member States and in those between the Institutions themselves, in the name of the community spirit and European democracy $^{80}$. In fact, also in consideration of what is happening recently with reference to the new MFF and the Recovery fund, with the initial veto of Poland and Hungary, the real problems to be solved are not only the structure of competences, the completion of the Economic and Monetary Union and the strengthening of the internal market, which would concern aspects of the efficiency of European action, but rather the democratic nature of the government of the economy by the EU, in which the centrality of the democratic decision is centred in the European Parliament ${ }^{81}$. Only in this perspective is it possible to effectively resume the process of integration which gives Europe an eminent international position, leads to the realization of the objectives and values of the EU and, at the same time, offers European citizens a common and meaningful identity. ${ }^{82}$

${ }^{79}$ See the position of European Council, Meeting of 12 December 2019 - Conclusions, 12 December 2019, EUCO 29/19, which postpones the conclusion of the conference on the future of Europe to the end of 202.

80 As J. HABERMAS (2013) had already observed, regarding the Commission's Blueprint.

${ }^{81}$ See H.-J. BLANKE and R. BÖ'T'TNER, 2016, 243-286.

82 See, S. MANGIAMELI, 2012, 21-46; S. MANGIAMELI, 2010. 


\section{REFERENCES}

AUSTIN G., (2005) Reform in Europe after the 2005 Referendums, Foreign Policy Centre, Policy Brief, June 2005.

BAERG N.R., HALLERBERG M., (2016) Explaining Instability in the Stability and Growth Pact: The Contribution of Member State Power and Euroskepticism to the Euro Crisis, in Comparative Political Studies 2016, 9681009.

BARAT'TA R., (2009) Le competenze interne dell'Unione tra evoluzione e principio di reversibilità, in C. Zanghi \& L. Panella (a cura di), Il Trattato di Lisbona tra conferme e novità, Torino: Giappichelli, 2009, $109 \mathrm{ff.}$.

BARENTS R., (1997) Some Observations on the Treaty of Amsterdam, in Maastricht Journal of European and Comparative Law 1997, 332-345.

BARTOLE S., (2000) La cittadinanza e l'identità europea, in Quad. cost., 2000, 39 ss.

BEETSMA R., ULIGH A., (1999) An Analysis of the Stability and Growth Pact, in The Economic Journal, 1999, 546-571.

BENZ A., ZIMMER C., (2012) The EU's competences: The 'vertical' perspective on the multilevel system, in Living Reviews in European Governance, Vol. 5, No. 1, 2012, 1-31.

BINET C., (2020) L'Europe et son Green Deal: quel avenir pour le climat?, in Journal de droit européen, 2020, no. 269, 207-211.

BINI SMAGHI L., (2013) Austerity European Democracies Against the Wall, Centre for European Policy Studies, Brussels 2013.

BIONDI A., EECKHOUT P., RIPLEY S. (Eds), (2012) EU Law after Lisbon, Oxford University Press, Oxford, 2012.

BLANKE H.-J. - BÖTTNER R., (2016) The Democratic Deficit in the Economic Governance of the European Union, in H.-J. Blanke - P. Cruz Villalón - T. Klein - J. Ziller (Editors), Common European Legal Thinking -Essays in Honour of Albrecht Weber, Springer, Heidelberg, 2016, 243-286.

BLANKE H.-J., MANGIAMELI S., (2006) Governing Europe under a Constitution, Springer Heidelberg 2006. 
BLANKE H.-J. - MANGIAMELI S. (Eds.), (2012) The European Union after Lisbon. Constitutional Basis, Economic Order and External Action, Springer, Heidelberg, 2012.

BLANKE H.-J., (2003) Essentialia des Entwurfes des Europäischen Verfassungsvertrages, in Teoria del Diritto e dello Stato 2003, 95-148.

BLOKKER N. M., HEUKELS T., BRUS M.T.A. (Eds), (1998) The European Union After Amsterdam: A Legal Analysis, Kluwer Law International, 1998.

BLUMANN C., (1997) Le Traité d'Amsterdam. Aspects institutionnels, in RTDE, 1997, 74.

BRAAMS B., (2008) Die Kompetenzordnung im Vertrag von Lissabon, in I. Pernice (Ed.), Der Vertrag von Lissabon: Reform der EU obne Verfassung?, Baden Baden: Nomos, 2008, 115-134.

BRUNILA A., BUTI M., FRANCO D., (2001) The Stability and Growth Pact: The Architecture of Fiscal Policy in Emu, Palgrave MacMillan, London, 2001. BUSCH K., HERMANN C., HINRICHS K., SCHULTEN T., (2013) Euro Crisis, Austerity Policy and the European Social Model, Friedrich-EbertStiftung, Bonn 2013.

BUSIA G., (2003) Il ruolo della Convenzione europea in vista della sottoscrizione di nuovi trattati, in M.P. Caruso, F. Tufarelli (a cura di), Quale Europa, tra Convenzione, Conferenza intergovernativa e allargamento, Rubbettino, Soveria Mannelli, 2003 59-70;

CALLIES C., (1999) Art. 5 EG-Vertrag, in C. Callies, M. Ruffert, Kommentar zи EU-Vertrag und EG-Vertrag, Neuwied-Kriftel 1999, 307.

CARET'TI P., (1993) Il principio di sussidiarietà e $i$ suoi riflessi sul piano dell'ordinamento comunitario e dell'ordinamento nazionale, in Quad. Cost., 1993, 7 ss..

CARTABIA M., (1996) Cittadinanza europea, in Enc. giur., Aggiorn., 1996.

Caruso F., (2008) La disciplina dell'esercizio delle competenze di Stati membri ed Unione nel Trattato di Lisbona. In: Studi in onore di Umberto Leanza, Napoli: Editoriale Scientifica, 2008, $943 \mathrm{ff}$.

CASSESE S., (1996) La cittadinanza europea e le prospettive di sviluppo dell'Europa, in Riv. it. dir. pubbl. com., 1996, 869 ss. 


\section{Mangiameli ICOVID-19 AND EUROPEAN UNIONI ISSN 2675-1038}

CLOOS J. - Reinesch G. - Vignes D. - Weyland J., (1993) Le Traite de Maastricht: Genese, Analyse, Commentaires, Bruylant, Bruxelles, 1993.

CRAIG P., (2010) The Lisbon Treaty. Law, Politics, and Treaty Reform, Oxford University Press, Oxford, 2010.

CRAIG P., (2012) The Stability, Coordination and Governance Treaty: Principle, politics and Pragmatism, in European Law Review 2012, $231 \mathrm{ff.}$

CROONENBORGHS K., (2020) The European instrument for temporary support to mitigate unemployment risks in an emergency SURE, in EU Law Live, 2020, May 30, 1.

CUOCOLO F., (1991) La cittadinanza europea (prospettive costituzionali), in Pol. dir., 1991, 659 ss.

D’AGNOLO G., (1998) La sussidiarietà nell'Unione Europea, Padova 1998.

D'ATENA A., (2005) Modelli Federali e sussidiarietà nel riparto delle competenze normative tra l'Unione europea e gli Stati membri, in Dir. Un. Eu. 2005, 59 ss.

DANIELE L., (2006) Costituzione europea e riforma istituzionale dell'Unione, in Dir. Un. Eu., 2006, 1 ss.

DE BURCA G., (2006) After the referenda, in European Law Journal 2006, 6.

DE GRAUWE P., (2003)The Stability and Growth Pact in Need of Reform, Unpublished manuscript, 2003 (http://citeseerx.ist.psu.edu/viewdoc/download?doi=10.1.1.486.3493 \&rep $=$ rep1\&type $=$ pdf $)$.

DE GREGORIO MERINO A., (2012) Legal development in the Economic and Monetary Union during the debt crisis: the mechanism of financial assistance, in CMLR, 2012, 1634.

DE WITTE B., OTT A., VOS E. (Eds), (2017) Between Flexibility and Disintegration. The Trajectory of Differentiation in EU Law, Edward Elgar Publishing, Cheltenam UK, Northampton Ma Usa, 2017.

DE WITTE B., (2011) The European Treaty Amendment for the Creation of Financial Stability Mechanism, in European Policy Analysis, 2011, n. 6 (www.sieps.se).

DEHOUSSE R. (Ed.), (1994) Europe after Maastricht, Beck, München, 1994; DEHOUSSE R., (1997) Le Traité d'Amsterdam, Reflet de la Nouvelle Europe, in Cabiers de Droit Europeen 1997, 265. 
DIMOPOULOS A., (2014) The use of international Law as a tool for strengthening economic governance in the EU and its implications on EU institutional integrity, in M. Adams, P. Larouche, F. Fabrini (Eds), The constitutionalization of the EU budgetary constraints, Oxford University Press, Oxford 2014, 59.

DRAETTA U., (2004) La Costituzione europea e il nodo della sovranità nazionale, in Dir. Un. Europea 2004, 525.

DUFF A., PINDER J. \& PRYCE R., (1994) Maastricht and beyond: building the European Union, Routledge, London - New York, 1994;

DYSON K. - Featherstone K.,(1999) The Road to Maastricht. Negotiating Economic and Monetary Union, Oxford University Press, Oxford, 1999.

ELKERBOUT M., EGENHOFER C., NÚÑEZ FERRER J., CATUTI M., KUSTOVA I., RIZOS V., (2020), The European Green Deal After Corona: Implications for EU climate policy, CEPS Policy Insight 2020/6.

ESTERBAUER F., (1994) Europäische Integration. Von den Anfängen zum Vertrag von Maastricht, Braumüller, Wien, 1994;

EVERLING U., (1992) Die Stellung des Bürgers in der Europäischen Gemeinschaft, in ZFRV, 1992, 241 ss.;

FAVRET J.M., (1997) Le Traité d'Amsterdam: Une révision a minima de la "charte constitutionnelle" de l'Union européenne, in Cahiers de Droit Europeen 1997, 555;

FISCHER J., JONUNG L., LARCH M., (2006) 101 Proposals to reform the Stability and Growth Pact. Why so many? A Survey, European Commission, Directorate-General for Economic and Financial Affairs, Economic Papers, N²67 December 2006;

FOLZ H.P.,(2009) Die Kompeten zverteilung qwischen der Europäischen Union und den Mitgliedstaaten, in U. Fastenrath \& C. Nowak (Hrsg.), Der Lissabonner Reformvertrag - Änderungsimpulse in einzelnen Rechts- und Politikbereichen (p.). Berlin: Duncker \& Humblot, 2009, 65-75;

FRIEDERICH I., (2005) Quo vadis? Europe's role in a globalised World, in European view 2005, vol. 2, 53;

GARBEN S., GOVAERE I. (Eds), (2017) The Division of Competences between the EU and the Member States. Reflection on the Past, the Present and the Future. Oxford and Portland: Hart Publishing, 2017; 


\section{Mangiameli ICOVID-19 AND EUROPEAN UNIONI ISSN 2675-1038}

GRABITZ E., (1992) Subsidiarität im Gemeinschaftsrecht, in B. Vogel, H. Öttinger, Föderalismus in der Bewährung - die deutschen Länder vor der Herausforderung fortschreitender EG-Integration, Köln: Deutscher Gemeindeverlag, 1992, 139;

GROS D., (2012) Credible Austerity Plans Are Required, in Intereconomics 2012, 3, 175.

GUZZETTA G., BINDI F. (a cura di), (2009) Lo stato dell'Unione. L'Europa d'inizio millennio fra allargamento e costituzionalizzazione, Giappichelli, Torino, 2009.

HABERMAS J. (2013), Democracy, Solidarity and the European Crisis, Lecture delivered on 26 April 2013 in Leuven.

HAUPTMEIER S., LEINER-KILLINGER N., (2020) Reflections on the Stability and Growth Pact's Preventive Arm in Light of the COVID-19 Crisis, in Intereconomics 2020, 5, 296-300.

HEIPERTZ M., VERDUN A., (2010) Ruling Europe: The Politics of the Stability and Growth Pact, Cambridge University Press, Cambridge, 2010;

HENTSCHELMANN K., (2010) Der Stabilitäts- und Wachstumspakt als Ordnungsrahmen in Krisenzeiten. Möglichkeiten und Grenzen der Berücksichtigung der Finanzkrise, Europa-Kolleg Hamburg, Institute for European Integration, Discussion Paper Nr. 1/10, Januar 2010;

HERZOG B., (2004) The stability and growth pact and its institutional inconsistencies, Second Pan-European Conference - Standing Group on EU Politics, Bologna, 24-26 June 2004, http://www.jhubc.it/ecprbologna;

HOFFMANN L., (2002) The Convention on the Future of Europe - Thoughts on the Convention-Model, Jean Monnet Working Paper 11/02, NYU School of Law, New York, 2002.

JÄÄSKINEN N., (2011) Constitutions in the European Union - Some Questions of Conflict and Convergence, in ERA Forum 2011, 12: 205-218.

JURGENS F., (2010) Die Kompetenzabgrenzung zwischen der Europäischen Union und den Mitgliedstaaten, München: Herbert Utz Verlag, 2010;

KAHL W., (1993) Möglichkeiten und Grenzen des Subsidiaritätprinzips nach Art. $3 b$ EG-Vertrag, in A.ö.R., 1993, 414 ss.; 


\section{Mangiameli ICOVID-19 AND EUROPEAN UNIONI ISSN 2675-1038}

KARYOTIS G., GERODIMOS R. (Eds.), (2015) The Politics of Extreme Austerity. Greece in the Eurozone Crisis, Palgrave MacMillan, London 2015.

ROSS G., (1995) Jacques Delors and European Integration, Oxford University Press, Oxford, 1995.

VITERBO A., CISOT'TA R., (2010) La crisi della Grecia, l'attacco speculative all'euro e le risposte dell'Unione europea, in Dir. Un. Eu. 2010

von DER LEYEN U. (2019), A Union that strives for more. My agenda for Europe, Political Guidelines for the next European Commission 20192024.

WALKER N., (2006) Big “C” or small "c"?, in European Law Journal 2006, 12. WEBER A., (2012) The Distribution of Competences between the Union and the Member States, in H.-J. Blanke \& S. Mangiameli (Eds.), The European Union after Lisbon, Heidelberg: Springer, 2012, 311-322.

WEILER J.H.H., (1998) Bread and Circus: The state of the European Union, in Columbia Journal of European Law 1998, 223.

WYATT D., (2011) Is the EU an Organisation of Limited Powers? In: A Constitutional Order of States?, in Essays in EU Law in Honour of Alan Dashwood, Oxford: Hart Publishing, 2011, 3 ff.

ZILLER J., (2010) Bases juridiques et compétences en droit de l'Union européenne, in L'Union européenne: union de droit, union de droits. Mélanges en l'honneur du Professeur Philippe Manin, Paris, Pedone, 2010, 751 ff. 


\section{EUROPEAN UNION DOCUMENTS}

Conclusions of the President of the European Council following the video conference of the members of the European Council, 23 April 2020, Statements and Remarks, 251/20, 23/04/2020.

Council of the European Union, 26 June 2007, n. 11218/07, POLGEN 74,

Note from General Secretariat of the Council, to Delegations - Subject: IGC 2007 Mandate.

Council of the European Union, Multiannual Financial Framework (MFF) 2021-2027 and Recovery package - End of Written Procedure Communication of 14 December 2020, CM 5358/20.

Council of the European Union, Position of the Council at first reading with a view to the adoption of a Regulation of the European Parliament and of the Council on a general regime of conditionality for the protection of the Union budget - Statement of the Council's reasons - Adopted on 14 December 2020.

Council Regulation (EU) 2020/672 of 19 May 2020 on the establishment of a European instrument for temporary support to mitigate unemployment risks in an emergency (SURE) following the COVID-19 outbreak.

Declaration of the leaders of 27 Member States and of the European Council, the European Parliament and the European Commission", in European Council and Council of the European Union, Statements and Remarks, 149/17, 25/03/2017; and in European Commission, Statement 17/767, 25 March 2017.

ECB, Press Release of 18 March 2020, announced $€ 750$ billion Pandemic Emergency Purchase Programme (PEPP).

Eurogroup in inclusive format of 7-9 April 2020, 17 April 2020, ecfin.cef.cpe(2020)2329436, Report by the Eurogroup, in inclusive format, on the comprehensive economic policy response to the COVID-19 pandemic, 5/6, point 15. 


\section{Mangiameli ICOVID-19 AND EUROPEAN UNIONI ISSN 2675-1038}

European Commission, European Governance: A white paper, COM(2001) 428/final, 5.8.2001

European Commission COM(2017)2025 of 1 March 2017.

European Commission to issue EU SURE bonds of up to $€ 100$ billion as social bonds, Press Release, 7 October 2020.

European Commission, A blueprint for a deep and genuine economic and monetary union. Launching a European Debate, COM(2012) 777 final/2, 30.11.2012.

European Commission, Communication from the Commission to the Council on the activation of the general escape clause of the Stability and Growth Pact, of 20.3.2020, COM(2020) 123 final.

European Commission, Communication from the Commission to the European Parliament, the Council, the European economic and social Committee and the Committee of the Regions, Commission Work Programme 2020, A Union that strives for more, of 29.1.2020 COM(2020) 37 final.

European Commission, Communication from the Commission to the European Parliament, the European Council, the Council, the European Central Bank, the European Investment Bank and the Eurogroup, Coordinated economic response to the COVID-19 Outbreak, of 13.3.2020, $\operatorname{COM}(2020) 112$ final, page 11.

European Commission, Communication from the Commission to the European Parliament, the European Council, the Council, the European Central Bank, the European Investment Bank and the Eurogroup, Coordinated economic response to the COVID-19 Outbreak, of 13.3.2020, $\operatorname{COM}(2020) 112$ final.

European Commission, Communication from the Commission to the European Parliament, the European Council, the Council, the European Economic and Social Committee and the Committee of the Regions, Europe's moment: Repair and Prepare for the Next Generation, of 27.5.2020, $\operatorname{COM}(2020) 456$ final.

European Commission, Communication from the Commission to the European Parliament and the Council, Shaping the Conference on the future of Europe, 22.1.2020, $\operatorname{COM}(2020) 27$ final. 
European Commission, EU SURE Social Bond Framework, 7 October 2020. European Commission, Letter from Executive Vice-President Dombrovskis and Commissioner Gentiloni to Eurogroup President Centeno clarifying how the Commission intends to carry out surveillance in the framework of the ESM's pandemic crisis support, of 07 May 2020.

European Commission, Proposal for a Council Regulation on the establishment of a European instrument for temporary support to mitigate unemployment risks in an emergency (SURE) following the COVID-19 outbreak, 2.4.2020, COM(2020) 139 final.

European Commission, Questions and Answers: European Commission to issue EU SURE bonds of up to $€ 100$ billion as social bonds, 7 October 2020.

European Council meeting in Laeken 14 and 15 December 2001, Presidency Conclusions, Laeken declaration on the future of Europe.

European Council, Joint statement of the Members of the of European Council 26 March 2020.

European Council, Meeting of 10, 11 December 2020 - Conclusions, 11 December 2020, EUCO 22/20

European Council, Meeting of 12 December 2019 - Conclusions, 12 December 2019, EUCO 29/19.

European Council, Special meeting of the 17, 18, 19, 20 and 21 July $2020-$ Conclusions, 21 July 2020, EUCO 10/20.

European Parliament resolution of 17 April 2020 on EU coordinated action to combat the COVID-19 pandemic and its consequences (2020/2616(RSP)) P9_TA-PROV(2020)0054.

European Parliament resolution of 17 December 2020 on the Multiannual Financial Framework 2021-2027, the Interinstitutional Agreement, the EU Recovery Instrument and the Rule of Law Regulation (2020/2923(RSP).

European Parliament, Compromise on long-term EU budget: EP obtains $€ 16$ billion more for key programmes, Press release, 10-11-2020 - 16:17, 20201106 IPR91014. 
European Parliament, Resolution of 23 July 2020 on the conclusions of the extraordinary European Council meeting of 17-21 July 2020 (2020/2732(RSP)).

Executive Office of the President - Council of Economic Advisers, The Economic Impact of the American Recovery and Reinvestment Act of 2009, Second Quarterly Report - January 13, 2010.

President of the Eurogroup, Letter to the President of the Euro Summit, of 15 June 2019.

President of the Eurogroup, Pascal Donohoe, Letter to the President of the European Council, Charles Michel, of 4 December 2020 and the Statement of the Euro Summit meeting, 11 December 2020, EURO 502/20.

President of the Eurogroup, Summing up letter, to the members of Eurogroup in inclusive format, on Eurogroup in inclusive format of 79 April 2020, 17 April 2020, ecfin.cef.cpe(2020)2329436, Report by the Eurogroup, in inclusive format, on the comprehensive economic policy response to the COVID-19 pandemic, 5/6.

President of the European Council and President of the Commission, $A$ roadmap for recovery - Towards a more resilient, sustainable and fair Europe, 21 April 2020.

President of the European Council, Conclusions following the video conference of the members of the European Council, 23 April 2020, Statements and Remarks, 251/20, 23/04/2020.

Press Release, Statement of the Eurogroup in inclusive format on the ESM reform and the early introduction of the backstop to the Single Resolution Fund, 839/20 30.11.2020. 
Report by Jean-Claude Juncker, in close cooperation with Donald Tusk, Jeroen Dijsselbloem, Mario Draghi and Martin Schulz, Completing Europe's Economic and Monetary Union. The Report of the five presidents was published on 12 June 2015 and presented at the European Council of June 2015, and discussed during the European Council meeting in December 2015. 